ABDI: Jurnal Pengabdian dan Pemberdayaan Masyarakat ISSN: 2656-369X (Print), 2684-8570 (Online)

Volume 2 No. 1, Juni 2020

http://abdi.ppj.unp.ac.id/index.php/abdi

Email: abdi@ppj.unp.ac.id

DOI: https://doi.org/10.24036/abdi.v2il.34

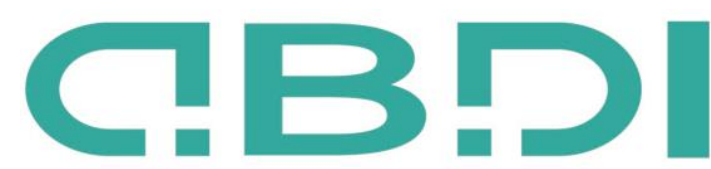

ABDI: JURNAL PENGABDIAN DAN PEMBERDAYAAN MASYARAKAT

\title{
Pemasaran Wisata Berbasis Website di Nagari Wisata Harau Kabupaten Lima Puluh Kota
}

\author{
Trisna Putra ${ }^{1}$, Pasaribu Pasaribu $^{2}$, Nidia Wulansari ${ }^{3}$ \\ ${ }^{1,2,3}$ Jurusan Pariwisata, Universitas Negeri Padang \\ E-mail: tputra@fpp.unp.ac.id
}

\begin{abstract}
Abstrak
Salah satu tantagan bagi daerah tujuan wisata dalam revolusi industri 4.0 adalah keberadaan sistem informasi daerah tujuan wisata. Website menjadi salah satu media yang potensial untuk membangun citra positif daerah tujuan wisata di dunia maya. Hal ini harus diantisipasi pengelola daerah tujuan wisata akibat persaingan yang sangat tinggi. Nagari Harau merupakan daerah tujuan wisata alam unggulan di Kabupaten Lima Puluh Kota. Namun dalam dunia maya kawasan ini tidak terekspos secara maksimal. Keterbatasan kemampuan pihak pengelola dalam mempromosikan melalui website adalah kendala utama yang dihadapi. Untuk memenuhi kebutuhan kegiatan pemasaran secara online maka dilakukan kegiatan pengabdian pada masyarakat dengan metode action learning terhadap kelompok Sadar Wisata (pokdarwis) Nagari Harau. Hasil kegiatan menunjukan keberhasilan dengan indikasi berupa tingginya antusisme peserta. Parameter kesuksesan lainnya dapat dibuktikan dengan dengan aspek kognitif 95\%, aspek afektif 95\% serta aspek konatif 85\%.
\end{abstract}

Kata kunci: Kabupaten Lima Puluh Kota, Nagari Harau, Pemasaran, Website.

\section{Abstract}

The challenge of tourism destination in industrial revolution 4.0 is the existence of its information system. Website becomes one of the potential media to promote positive image of a tourism destination. Nagari Harau is one of potential tourist destinations at Lima Puluh Kota Regency, West Sumatera. However it's an existence as well as potencies was not sufficiently published on the internet. The main obstacle of this problem is the capability of the management, in this case called a pokdarwis, in promoting it at the internet through its official website. This in order to overcome the problem, a public service program was design to empower the member of pokdarwis in Nagari Harau. The method used in public service program is action learning. The result of the program after having a post test toward the participants is $95 \%$ for cognitive aspect, $95 \%$ for affective aspect and $85 \%$ for conative aspect. The result show that the participants enthusiasm to the program and their increasing capability as well as capacity in promoting destination through website

Keyword: Kabupaten Lima Puluh Kota, Nagari Harau, Marketing, Website

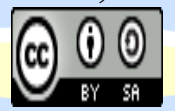

Received: 6 Desember 2019

Revised: 20 Januari 2020

Available Online: 21 Januari 2020 


\section{Pendahuluan}

Internet merupakan media potensial untuk menyebarkan informasi pariwisata daerah. Salah satu media informasi di internet yang sering dikunjungi oleh wisatawan untuk mendapatkan gambaran perjalanan liburan adalah website. Oleh karena itu, salah satu kegiatan promosi wisata daerah pada revolusi industri 4.0 yang penting dikembangkan adalah penggunaan media website. Promosi merupakan kegiatan penyebaran informasi untuk disampaikan pada konsumen atau calon wisatawan (Adhanisa \& Fatchiya, 2017). Pemasaran daerah tujuan wisata melalui website tersebut sangat efektif serta efisien dalam menghemat anggaran pemasaran (Milano, 2011). Banyak daerah yang telah sukses mempromosikan potensi daerah tujuan wisatanya melalui website. Salah satunya adalah Daerah Istimewa Yogjakarta dengan website; visitingjogja.com yang dinyatakan layak sebagai Best of the Best Tourism Website dalam kegiatan Indonesia's PR of The Year 2017 yang diselenggarakan oleh MIX Mar Comm-SWA Media Grup (MIX MarComm-SWA Media Grup) Dinas Pariwisata DIY Meraih Penghargaan Indonesia's PR of The Year 2017, 2017).

Salah satu hal yang perlu diperhatikan dalam pengembangan website daerah tujuan wisata adalah kebiasaan calon pengunjung mencari informasi sebanyak mungkin tentang daerah yang akan di datangi. Keadaan ini sesuai dengan survei Visa Global Travel Intention Study, (Brown, 2015) bahwa wisatawan $71 \%$ menyatakan sumber pencarian informasi perjalanan didapatkan dari digital atau website. Menurut (Prasetya, 2011) media sosial mampu menyebarkan informasi dengan cepat dan daya jangkau yang luar biasa dibandingkan dengan media manapun. Penjelasan yang serupa (Nursastri, 2013), traveling sebagai prioritas kedua orang Indonesia dipengaruhi oleh media sosial. Wisatawan mencari ide wisata lewat facebook, twitter, dan jejaring sosial lainnya. Terdapat $65 \%$ wisatawan mencari ide berwisata melalui pencarian sosial.

Penggunaan media online dalam melakukan penyebaran informasi terutama tentang kepariwisataan sangat didukung oleh pemerintah. Dalam Peraturan Menteri Pemberdayaan Aparatur Negara dan Reformasi Birokrasi (Permenpan) Nomor 83 tahun 2012 tentang Pedoman Pemanfaatan Media Sosial Instansi Pemerintah menyatakan bahwa, penggunaan media sosial telah membentuk dan mendukung cara baru dalam berkomunikasi, berinteraksi, dan berkolaborasi. Media sosial menawarkan cara yang lebih cepat dan tepat untuk berpartisipasi dalam pertukaran informasi melalui daring (dalam jaringan atau online) (Menteri Pendayagunaan Aparatur Negara dan Reformasi Birokrasi, 2013).

Namun tidak semua website akan memberikan informasi yang memadai bagi calon pengunjung tersebut. Menurut penelitian yang dilakukan oleh User Interface Engineering, Inc. (Leavitt, 2006), diketahui $60 \%$ waktu terbuang karena orang tidak bisa menemukan informasi yang ingin didapat dan hal ini berdampak pada penurunan produktivitas dan meningkatkan frustasi. Hal tersebut berakibat kepada kepercayaan calon pengunjung kepada daerah wisata tersebut. oleh karena itu ada dua hal yang perlu diperhatikan bagi daerah tujuan wisata yang akan bersaing dalam industri pariwisata, pertama adalah keberadaan website daerah dan kedua adalah ketersediaan informasi yang ditampilkan dalam website terebut. Penggunaan media sosial yang tepat diantaranya adalah dengan proses persuasi dan menjalin kedekatan emosional sehingga dapat meningkatkan kepercayaan para pengikut akun tersebut terhadap informasi yang diberikan (Hamzah, 2015).

Nagari Harau merupakan salah satu daerah tujuan wisata yang potensial di Kabupaten Lima Puluh Kota Sumatera Barat. Potensi Nagari Harau tersebut berupa hutan tropis dengan tebing tinggi yang mengelilinginya. Daerah ini didominasi oleh topografi landai dengan luas 4.350 Ha, agak curam $2.580 \mathrm{Ha}$, sangat curam $1.900 \mathrm{Ha}$, curam $1.653 \mathrm{Ha}$, dan datar 1.120 Ha. Selain keindahan alam tersebut, potensi yang ada pada nagari ini adalah kekayaan adat budaya masyarakat yang masih terjaga. Salah satu perhelatan budaya anak nagari yang rutin diadakan setiap tahunnya adalah "pasa harau". Namun secara virtual, informasi kawasan ini masih sedikit karena belum memiliki website promosi pariwisata. Oleh karena itu, masih banyak calon pengunjung yang belum mengetahui keberadaan Nagari Harau. Eksistensi serta promosi daerah ini masih sebatas word of mouth atau dari mulut ke mulut. Selain itu informasi atau foto kawasan dapat ditemui dalam blog, facebook dan instagram wisatawan yang kurang memberikan penjelasan lebih mendalam. Secara mandiri, pusat informasi yang terintegrasi dari Nagari Harau belum ada. Untuk itu perlu pemberdayaan masyarakat terutama kelompok sadar wisata sebagai pengelola kegiatan wisata di Nagari Harau. Dengan adanya 
kegiatan pemberdayaan kelompok sadar wisata terhadap pemasaran wisata berbasis website di Nagari Harau maka keberadaan potensi Nagari Harau dapat di publikasikan secara intensif dan effisien. Selain itu, kegiatan masyarakat setempat baik berupa festival maupun ritual adat juga dapat dipublikasikan pada media website tersebut. Informasi tentang sarana dan prasarana yang ada di Nagari Harau dapat diketahui oleh calon pengunjung yang akan mendatangi Nagari Harau. Hal yang terpenting adalah dengan website tersebut interaksi calon pengunjung dengan pengelola Nagari Harau dapat terjalin secara intensif.

Program kegiatan PKM Pelatihan Pemasaran Wisata Berbasis Website bagi Pokdarwis di Nagari Wisata Harau adalah salah satu usaha pemberdayaan masyarakat dalam hal ini kelompok sadar wisata (pokdarwis). Kegiatan ini dilaksanakan dengan menggunakan metode action learning dimana kelompok sadar wisata diajak bekerjasama dalam membangun atau membuat konsep website tersebut. peserta terdiri atas lima orang dan dilakasanakan di kantor informasi pariwisata dinas pariwisata pemuda dan olah raga Kabupaten Lima Puluh Kota.

\section{Metode Pelaksanaan}

Metode yang digunakan dalam program kegiatan Pelatihan Pemasaran Wisata Berbasis Website bagi Pokdarwis adalah action learning. Metode ini diberikan untuk memungkinkan peserta pelatihan bisa menganalisis dan memecahkan masalah pemasaran yang ada di Nagari Harau. Metode ini merupakan suatu cara untuk menyampaikan ide dan gagasan melalui proses menemukan secara bersama (Citra et al., 2018). Karakteristik Action Learning menurut (Gifford \& Building, 2005) yaitu, kegiatan yang bersifat belajar dari pengalaman atau belajar langsung. Topik yang difokuskan dalam kelompok dibahas dengan beragam pemahaman yang telah dimiliki oleh peserta pelatihan dengan masing-masing anggota kelompok meyakini kemampuan yang dimilikinya. Tahapan pelaksanaan metode action learning meliputi kegiatan sebagai berikut: 1. menetapkan tujuan, 2. menggali informasi dari anggota kelompok, 3. menganalisis isu - isu yang berkembang, 4. mempresentasikan masalah, 5. menetapkan strategi, 6. pelaksanaan tindakan dan 7. menampilkan hasil.

Pada kegiatan Pelatihan Pemasaran Wisata Berbasis Website ini metode action learning diadopsi dengan tahapan sebagai berikut: tahapan pertama adalah identifikasi dan analisis situasi dengan group atau kelompok sadar wisata Nagari Harau yang kemudian menetapkan tujuan kegiatan pemasaran. Tahapan kedua adalah melakukan kegiatan penggalian informasi dari kelompok sadar wisata Nagari Harau dengan menganalisis isu - isu yang berkembang seputar potensi wisata serta permasalahannya. Tahapan ketiga adalah menetapkan strategi dalam pemasaran dalam bentuk kerangka web yang akan di tampilkan. Tahapan keempat adalah melakukan tindakan dengan memverifikasi konten web tersebut dengan kelompok sadar wista nagari harau. Tahapan kelima adalah menampilkan hasi dalam bentuk media informasi dalam sebuah website Nagai Harau. Tahapan terakhir yang dilakukan adalah evaluasi terhadap hasil kegiatan yang telah dilakukan.

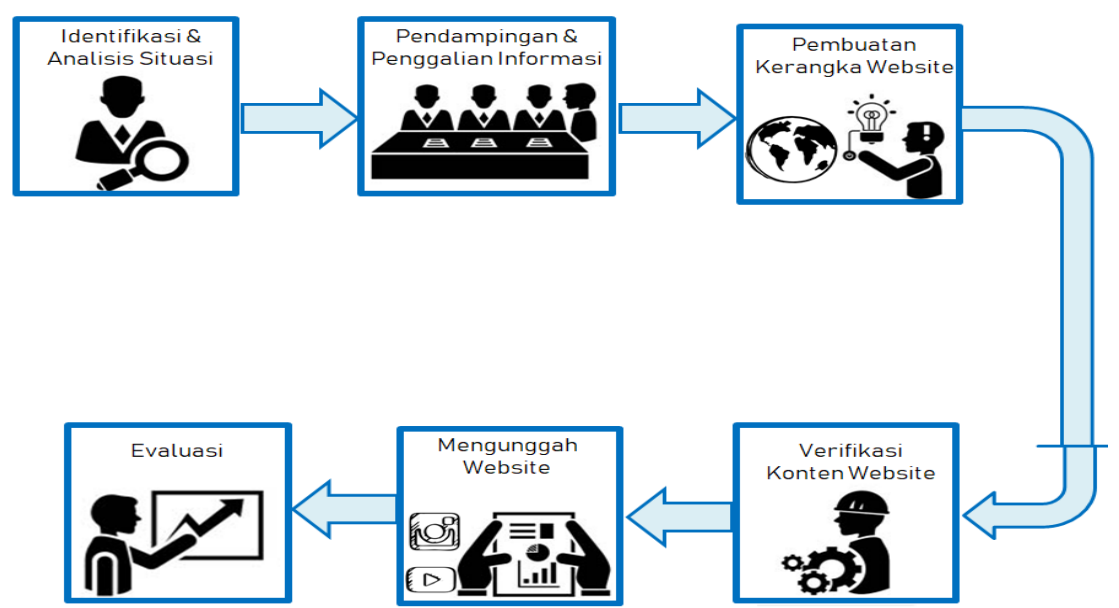

Gambar 1. Metode Pelaksanaan Kegiatan 
Nagari Harau adalah salah satu Nagari yang terletak di Kecamatan Harau yang berada di Kabupaten Lima Puluh Kota. Jarak tempuh wilayah Nagari Harau dari Kota Padang adalah $\pm 139 \mathrm{Km}$ serta $\pm 47 \mathrm{Km}$ dari Bukittinggi dan sekitar $\pm 18 \mathrm{Km}$ dari Kota Payakumbuh dan $\pm 2 \mathrm{Km}$ dari Pusat Kota. Nagari ini memiliki luas wilayah $11.603 \mathrm{~km} 2$, dengan potensi lahan yang produktif. Batas wialayah Nagari sebagai berikut:

Sebelah Utara

Sebelah Timur

: Nagari Sarilamak dan Nagari Tarantang

Sebelah Selatan

Sebelah Barat

Kab. Kampar Riau

: Kec. Pangkalan

: Nagari Solok Bio-Bio dan Kec. Mungka

Nagari Harau terdiri dari tujuh Jorong yaitu; Jorong Harau, Jorong Padang Torok, Jorong Koto, Jorong Koto Marapak, Jorong Batu Badukuang, Jorong Sungai Data dan Jorong Landai. Topogarfi Nagari Harau terdapat dataran, landai dan berbukit yang terdiri dari bukit batu, keberadaan nagari ini terletak di tepi kawasan hutan, berada pada ketinggian antara $600 \mathrm{~m}$ sampai $1120 \mathrm{~m}$ diatas permukaan laut. Sebagian besar susunan vegetasi Nagari Harau merupakan tipe vegetasi Hutan Hujan Tropis pegunungan yang masih primer dan jenis pohon penyusun vegetasi tersebut didominasi oleh famili Lauraceae, Myrtaceae, Gurtaceae, Guttiferae dan Dipteraceae. Jenis pohon yang dominan adalah jenis Medang (Litsea sp), Kalek (Eugenia sp) dan Gambir (Fam.araucaceae). Sedangkan jenis lainnya adalah Cemara (Pygeum parviflorium), Banir (Shorea platycladas), Meranti bunga (Shorea sp) juga Surian hutan. (Toona sureni).

Di Nagari Harau dapat dijumpai jenis-jenis satwa yang dilindungi ataupun yang tidak, antara lain: Harimau Sumatra (Panthera tigris sumatraensis), Kambing Hutan (Nemerhaedus sumatraensis), Siamang (Hylobates syndaetylus), Rusa (Rusa timorensis), Tapir (Tapirus indicus), Kuau (Argusiamus argus) dan beberapa jenis burung. Secara umum potensi wisata yang ada pada Nagari Harau dapat dilihat dari tabel berikut ini:

Tabel 1. Potensi Wisata Nagari Harau

\begin{tabular}{rlll}
\hline No & \multicolumn{1}{c}{ Nama Daerah Tujuan Wisata } & Jenis Wisata & \multicolumn{1}{c}{ Kecamatan } \\
\hline 1 & Lembah Harau & Alam & Harau \\
\hline 2 & Aia Baba & Alam & Halaban \\
\hline 3 & Aia Songsang & Alam & Payakumbuh \\
\hline 4 & Aia Terjun Burai & Alam & Harau \\
\hline 5 & Batang Maek & Alam & Halaban \\
\hline 6 & Batang Tabik & Alam & Luhak \\
\hline 7 & Bukik Bulek & Alam & Harau \\
\hline 8 & Bukik Posuak & Alam & Bukit barisan \\
\hline 9 & Genangan Waduk PLTA & Alam & Pangkalan Koto Baru \\
\hline 10 & Ikan Larangan & Alam & Gunuang Omeh \\
\hline 11 & Kapalo Banda & Alam & Harau \\
\hline 12 & Kawasan Simona & Alam & Situjuan Limo Nagari \\
\hline 13 & Kelok Sembilan & Alam & Harau \\
\hline 14 & Kurai View & Alam & Gunuang Omeh \\
\hline 15 & Panorama Bukik Topuang & Alam & Payakumbuh \\
\hline 16 & Reas Area & Alam & Harau \\
\hline 17 & Sarasah Talang & Alam & Harau \\
\hline 18 & Sarasah Tanggo & Alam & Harau \\
\hline 19 & Tungka View & Alam & Payakumbuh \\
\hline 20 & Medan Nan Bapaneh & Budaya & Harau \\
\hline 21 & Perkampungan Tradisional & Budaya & Guguak \\
\hline 22 & Rumah Gadang Ukiran Cino & Budaya & Payakumbuh \\
\hline 23 & Rumah Gadang Sungai Baringin & Budaya & Payakumbuh \\
\hline 24 & Arkeologi Belubus & Sejarah & Guguak \\
\hline & & ABDI: Jurnal Pengabdian dan Pemberdayaan Masyarakat Vol. 2 No. 1 \\
& & CopyrightO 2020, By Author \\
\hline
\end{tabular}




\begin{tabular}{rlll}
\hline 25 & Makan Pahlawan Situjuah Batua & Sejarah & Situjuah Limo Nagari \\
\hline 26 & Makam Syeh Piobang & Sejarah & Guguak \\
\hline 27 & Menhir Batu Nan Limo & Sejarah & Guguak \\
\hline 28 & Rumah Tua Tan Malaka & Sejarah & Gunuang Omeh \\
\hline 29 & Talempong Batu & Sejarah & Harau \\
\hline 30 & Tugu PDRI & Sejarah & Guguak \\
\hline 31 & Benteng Tuanku Nan Garang & Sejarah & Payalumbuh \\
\hline 32 & Ngalau Seribu & Alam & Luak \\
\hline 33 & Air Panas Batu Balang & Alam & Harau \\
\hline 34 & Goa Aia Luluih Nagar & Alam & Situjuah Limoi \\
\hline 35 & Taman Anak Akabarayun & Buatan & Harau \\
\hline 36 & Bukik Lontiak & Alam & Payakumbuh \\
\hline 37 & Purituzana & Buatan & Bukik Barisan \\
\hline 38 & Ngalau Gunung Kambing & Alam & Situjuah Limo Nagari \\
\hline 39 & Aia Terjun Sialang Indah & Alam & Situjuah Limo Nagari \\
\hline 40 & Ngalau Malanteh & Alam & Luak \\
\hline 41 & Ngalau Galamadin & Alam & Luak \\
\hline 42 & Ngalau Hantu & Alam & Lareh Sago Halaban \\
\hline 43 & Goa Sago & Alam & Luak \\
\hline 44 & Air Terjun Singkapau & Alam & Suliki \\
\hline 45 & Goa Imam Bonjol & Alam & Gunuang Omeh \\
\hline 46 & Panorama Selat Malaka & Alam & Pangkalan Koto Baru \\
\hline 47 & Aia Panas Muaro Pati & Alam & Kapur IX \\
\hline 48 & Puncak Seribu Gonjong Kt. Tinggi & Alam & Bukik Barisan \\
\hline 49 & Batu Manunjang & Sejarah & Payakumbuh \\
\hline 50 & Makam Saleh Abdul Rahman Batu Hampa & Sejarah & Akabiluru \\
\hline 51 & Kawasan Menhir Maek & Sejarah & Bukik Barisan \\
\hline 52 & Tugu PDRI Tanjung Gadang & Sejarah & Guguak \\
\hline 53 & Kuburan Keramat/Surou Tuo Taram & Sejarah & Harau \\
\hline 54 & Menhir Gurun & Sejarah & Gunuang omeh \\
\hline 55 & Makam/Surau Syekh Abbas Abdullah Pdg Jpg & Sejarah & Guguak \\
\hline 56 & Batu Basurek Koto Lamo & Sejarah & Kapur IX \\
\hline 57 & Sakidomura & Sejarah & Pangkalan Koto Baru \\
\hline 58 & Pilubang Resort & Alam & Harau \\
\hline & & & \\
\hline & & & \\
\hline
\end{tabular}

Potensi Nagari Harau yang cukup banyak merupakan daya tarik bagi wisatawan tidak saja domestic tetapi juga wisatawan manca Negara. Hamper setiap tahun pertambahan jumlah wisatawan semakin meningkat jika dilihat dari perkembangan pertambahan wisatawan dalam 5 tahun terakhir dari tahun 2017 maka puncak kunjungan wisatawan berada pada tahun 2017. Hal ini dapat dilihat dari table berikut ini:

Tabel 2. Jumlah Wisatawan yang datang ke Nagari Harau

\begin{tabular}{cccccc}
\hline No & Tahun & $\begin{array}{c}\text { Wisatawan } \\
\text { Nusantara }\end{array}$ & $\begin{array}{c}\text { Wisatawan } \\
\text { Undangan }\end{array}$ & $\begin{array}{c}\text { Wisatawan } \\
\text { Mancanegara }\end{array}$ & Jumlah \\
\hline 1 & 2013 & 79.823 & 26.310 & 2.009 & 108.142 \\
\hline 2 & 2014 & 109.083 & 23.880 & 1.626 & 134.589 \\
\hline 3 & 2015 & 115.350 & 39.570 & 2.214 & 157.134 \\
\hline 4 & 2016 & 142.346 & 60.074 & 2.219 & 204.639 \\
\hline
\end{tabular}




\section{Hasil dan Pembahasan}

\section{Implementasi Kegiatan}

Sebelum kegiatan ini dilakukan maka diadakan pre test untuk mengetahui pengetahuan peserta terhadap kegiatan pemasaran wisata berbasis website di daerah tujuan wisata. Setelah pre test maka dilakukan penyuluhan atau sosialisasi tentang pentingnya kegiatan pemasaran berbasis website. Tahapan pertama adalah identifikasi and analisis situasi dengan group atau kelompok sadar wisata Nagari Harau yang kemudian menetapkan tujuan kegiatan pemasaran. Pada tahapan ini dilakukan brain storming dengan kelompok sadar wisata nagari harau yang berjumlah lima orang. Kelima anggota kelompok sadar wisata ini berasal dari berbagai bidang antara lain; aparatur kanagarian, pelajar, guru honorer, pelaku usaha kecil menengah (UKM), ibu rumah tangga. Peserta merupakan anggota kelompok sadar wisata (pokdarwis) yang tergabung dalam seksi promosi dan humas.

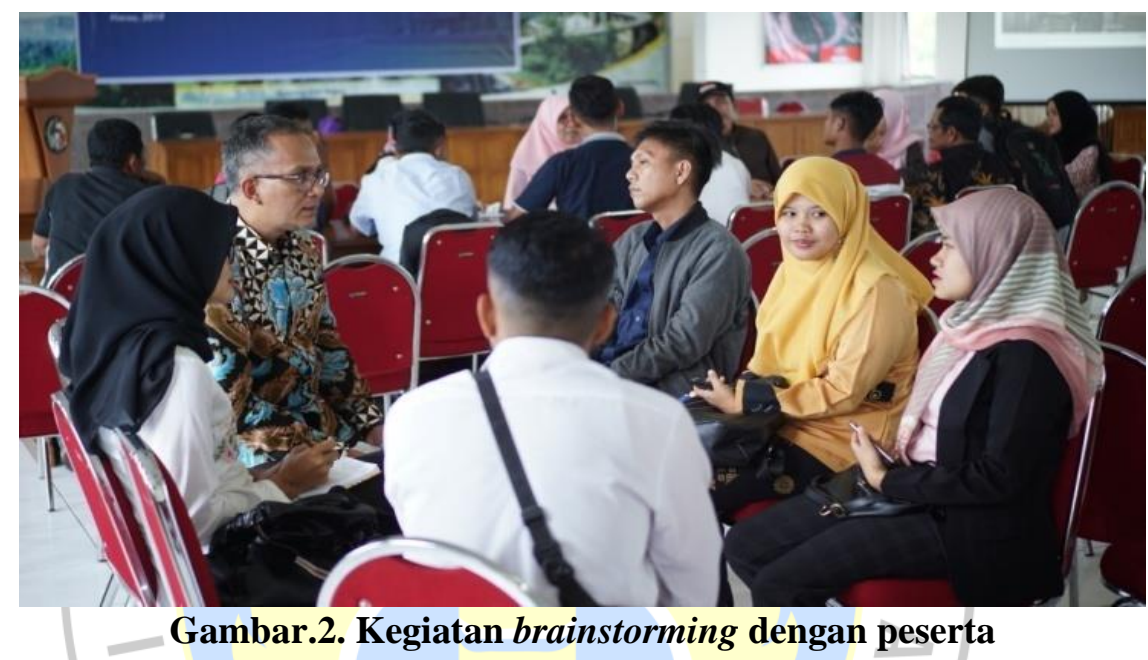

Tahapan kedua adalah melakukan kegiatan penggalian informasi dari kelompok sadar wisata Nagari Harau dengan menganalisis isu-isu yang berkembang seputar potensi wisata serta permasalahannya. Dalam tahapan ini perserta melakukan diskusi terkait potensi alam dan budaya yang ada di Nagari Harau. Selain itu diskusi dilanjutkan dengan sarana dan prasarana yang ada di Nagari Harau, mulai dari jalan, tempat ibadah, kemanan, rumah makan serta home stay. Sedangkan permasalahan yang ada pada nagari harau adalah keterbatasan akses telekomunikasi. Dari potensi dan permasalahan yang ada maka disusun strategi pengembangan pemasaran. Sebelum perancangan kerangka website, hal yang dilakukan adalah menetapkan konsep web tersebut. mengingat Nagari Harau adalah daerah dengan potensi alam berupa hamparan tanaman tropis yang hijau serta tebing tinggi yang mengelilingi maka di konsep branding yang merepresentasikan Nagari Harau tersebut.

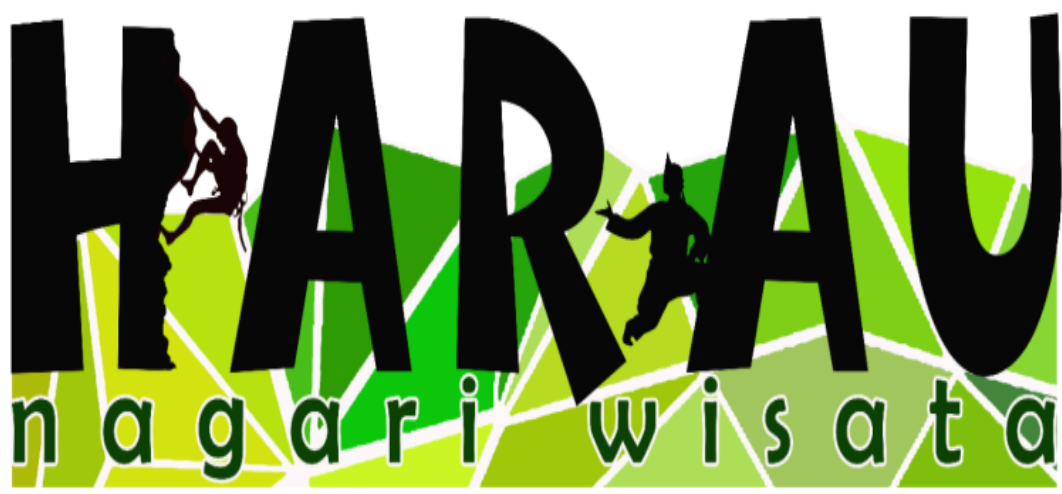

Gambar.3. Branding Nagari Harau 
Setelah brand didapatkan maka diciptakan slogan yang dapat merepresentasikan keunggulan Nagari Harau tersebut. Slogan dimaksud adalah Let nature heal your soul. Slogan ini akan menjadi bahagian dari website.

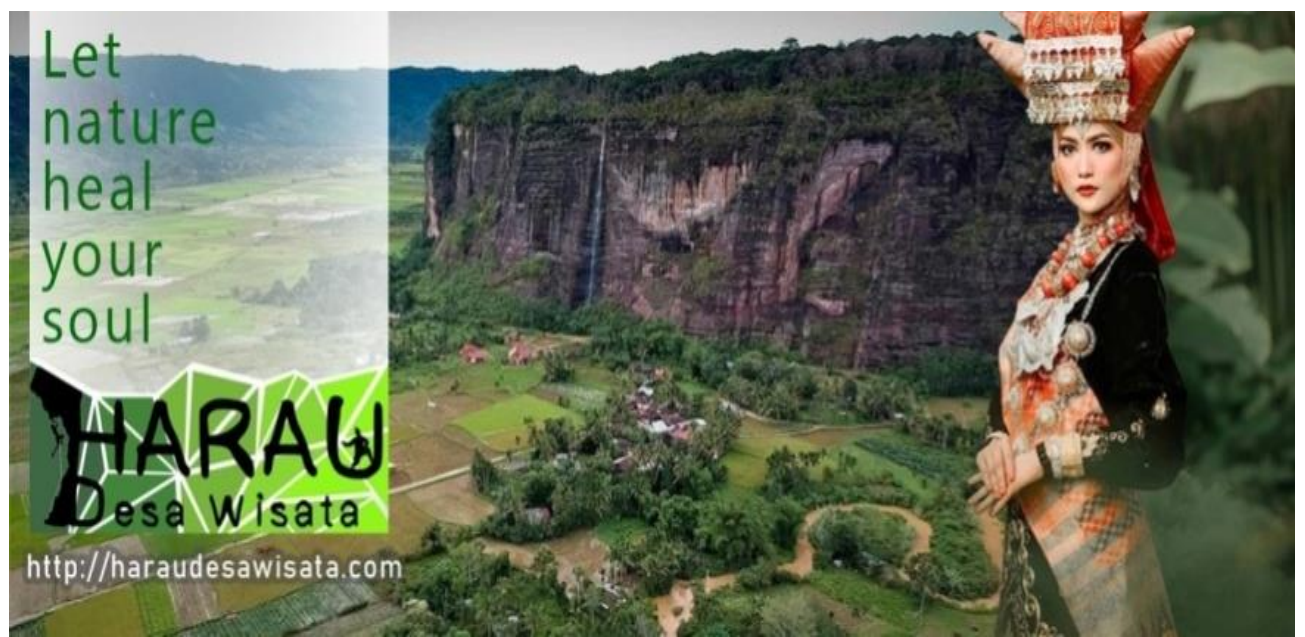

\section{Gambar.4. Slogan dan tampilan pada website}

Tahapan keempat adalah melakukan tindakan dengan memyerifikasi konten web tersebut dengan kelompok sadar wista Nagari Harau.

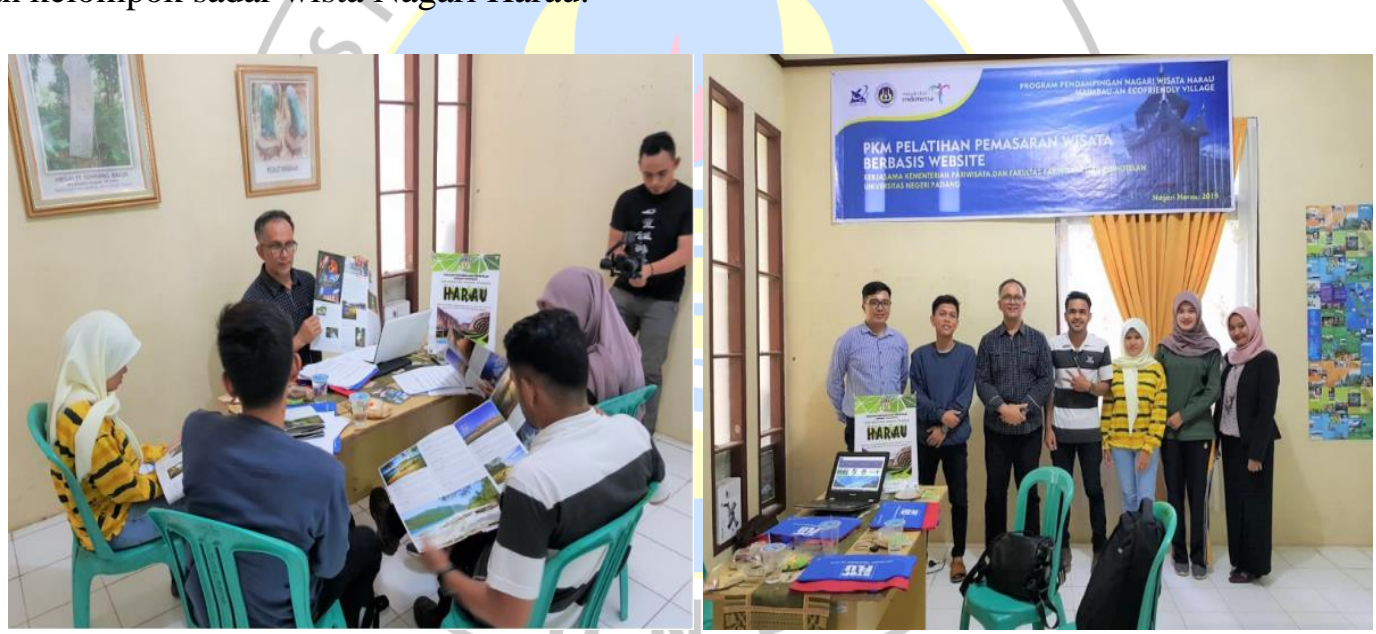

\section{Gambar.5. Verifikasi konten website}

Tahapan kelima adalah menampilkan gagasan, konsep serta hasil diskusi dalam bentuk media informasi dalam sebuah website Nagai Harau dengan alamat web: http://haraudesawisata.com

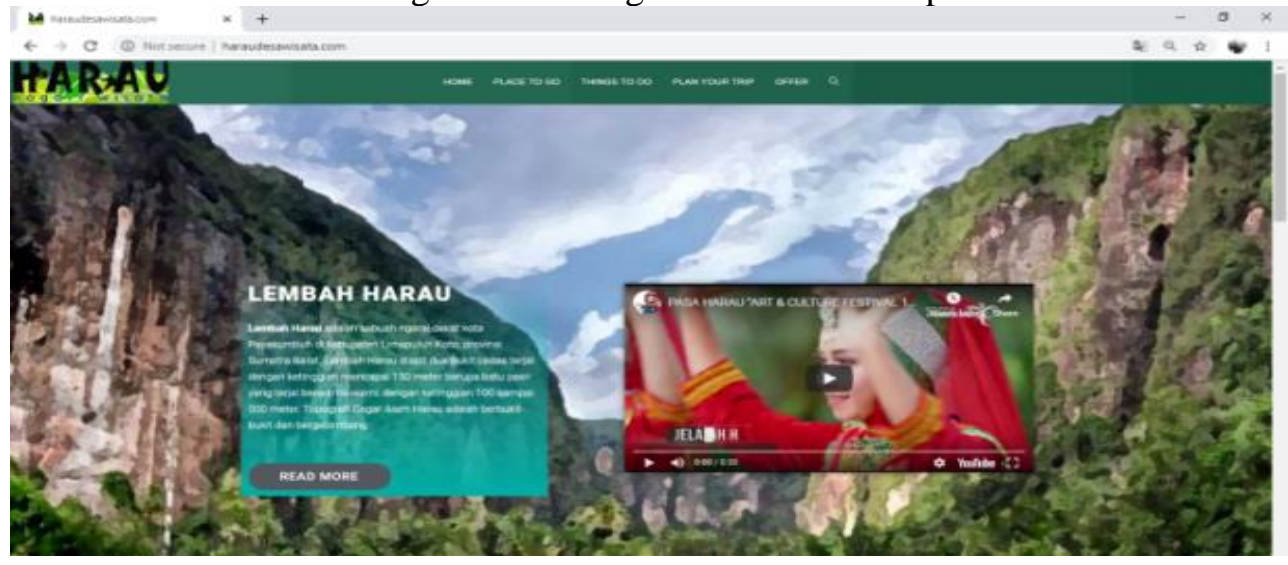




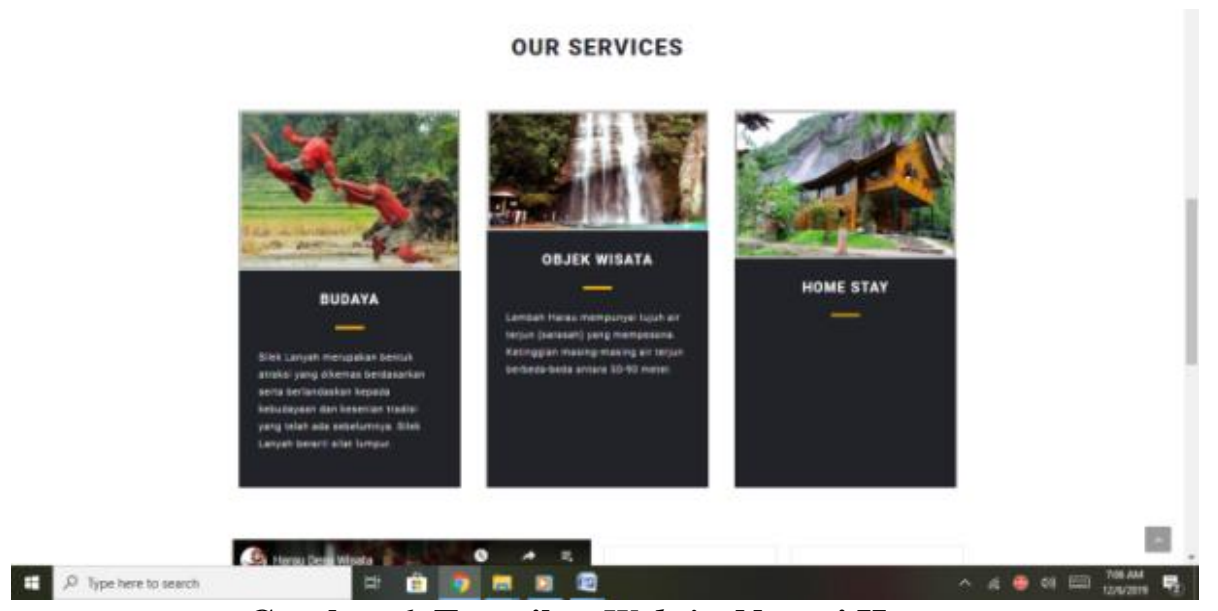

Gambar.6. Tampilan Website Nagari Harau

\section{Evaluasi Kegiatan}

Kegiatan pengabdian kepada masyarakat dengan program pemasaran wisata berbasis website yang dilaksanakan kepada masyarakat Nagari Harau menghasilkan produk sebuah website pariwisata. Website tersebut masih dalam tahap pengembangan dan perlu pemutakhiran data secara proaktif. Pelatihan yang telah dilakukan dapat berhasil membuka peluang kreativitas bagi kelompok sadar wisata yang ada di kawasan Nagari Harau Kabupaten Lima Puluh Kota. Kreativitas tersebut sangat dibutuhkan pada industri pariwisata tidak hanya dalam pengembangan daerah tujuan wisata (Putra, 2017) tetapi juga kreatif dalam mengembangkan media informasi atau pemasaran daerah tersebut. Program kegiatan pengabdian tersebut memfasilitasi peserta dengan materi yang diseleksi dan aplikatif sehingga dapat dipahami oleh peserta. Hal ini dilandasi dengan pemahaman bahwa bahan materi dan penyampaian harus dapat merubah cara berpikir peserta sehingga peserta berkeinginan untuk belajar, siap belajar, dan alasan tetap mau belajar (Suharto, 2005). Guna untuk mengetahui efektifitas penyampaian materi yang dilakukan maka dilakukan uji pretest dan posttest. Tujuan dari ujian ini adalah untuk mengetahui sejauh mana proses hasil pembelajaran yang disampaikan oleh pemateri terhadap peserta. Adapun hasil tes pengetahuan mengenai konsep dasar komunikasi efektif adalah sebagai berikut:

Tabel. 3 Hasil Uji Pretest dan Postest

\begin{tabular}{lcccccc}
\hline \multirow{2}{*}{ Kegiatan } & \multicolumn{3}{c}{ Pra Test (20 orang) } & \multicolumn{2}{c}{ Post Test (20 orang) } \\
\cline { 2 - 6 } & Setuju & Cukup & $\begin{array}{c}\text { Tidak } \\
\text { Setuju }\end{array}$ & Setuju & Cukup & $\begin{array}{c}\text { Tidak } \\
\text { Setuju }\end{array}$ \\
\hline $\begin{array}{l}\text { Aspek } \\
\begin{array}{l}\text { Kognitif } \\
\text { Mengetahui }\end{array}\end{array}$ & $50 \%$ & $40 \%$ & $10 \%$ & $95 \%$ & $5 \%$ & $0 \%$ \\
\hline $\begin{array}{l}\text { Aspek Afektif } \\
\text { Merasa perlu }\end{array}$ & $50 \%$ & $45 \%$ & $5 \%$ & $95 \%$ & $5 \%$ & $0 \%$ \\
\hline $\begin{array}{l}\text { Aspek Konatif } \\
\text { Dapat } \\
\text { melakukan }\end{array}$ & $5 \%$ & $70 \%$ & $25 \%$ & $85 \%$ & $15 \%$ & $0 \%$ \\
\hline
\end{tabular}

Berdasarkan data tabel 3. diatas menunjukkan bahwa secara kuantitatif pengetahuan peserta mengenai konsep pemasaran kawasan wisata berbasis online sebesar 50\% pada awal dilakukan pelatihan. Namun, setelah dilakukan penyampaian materi pengetahuan peserta meningkat menjadi $95 \%$. Untuk aspek afektif, posisi hasil pretest menunjukkan sebesar $50 \%$, yang artinya peserta paham betul dengan pentingnya pemasaran melalaui website. Setelah penyampaian materi, nilai postest yang dihasilkan cukup signifikan meningkat sebesar $95 \%$ yang menyatakan bahwa perlu dilakukan pelatihan. Sedangkan untuk penilaian pretest mengenai aspek konatif, nilai peserta hanya $5 \%$ yang menyatakan bisa melakukan pemasaran wisata Nagari Haru melalui media sosial namun dalam bentuk 
website belum mampu. Sedangkan $85 \%$ hasil postest menunjukkan ada peningkatan kemampuan peserta dalam mempromosikan daerah tujuan wisata melalui website. Tingginya minat peserta terhadap pelatihan tersebut harus disikapi oleh semua stakeholder yang ada seperti pemeritah, pihak swasta dan yang lainnya. Keberadaan stakeholder ini sangat penting dalam pengembangan daerah tujuan wisata tidak hanya berupa pembangunan fisik bangunan tetapi juga pemasaran daerah tersebut. Keterlibatan gabungan beberapa stakeholder tersebut dinamakan dengan pentahelix. Stakeholder yang tergabung dalam pentahelix tersebut adalah pemerintah, masyarakat, akademisi, swasta, dan sosial entrepreneur (Putra, 2019). Melalui kelima aktor tersebut maka kerjasama bidang pemasaran akan semakin maksimal serta informasi yang ditampilkan dalam website daerah tujuan wisata Nagari Harau akan semakin berkembang.

\section{Kesimpulan}

Pemasaran daerah tujuan wisata melalui website adalah hal yang penting terutama bagi Nagari Harau. Hal ini dikarenakan oleh perkembangan teknologi informasi yang semakin pesat dan pencarian informasi daerah tujuan wisata melalui internet semakin meningkat. Selain itu tidak adanya website Nagari Harau merupakan faktor utama dalam kegiatan pemasaran berbasis website. Metode yang dilakukan dalam kegiatan adalah action learning terhadap kelompok sadar wisata nagari harau yang tergabung dalam seksi pemasaran dan humas. Hasil dari kegiatan adalah aspek kognitif peserta sebesar 95\%, aspek afektif peserta sebesar 95\% dan aspek konatif peserta sebesar $85 \%$. Kegiatan pemasaran ini harus tetap di kembangkan serta pemutakhiran data yang ada dalam website yang sudah dihasilkan harus tetap proaktif. Untuk itu disaran ken kepada pemerintah terutama dinas dan instansi terkait untuk tetap mendampingi tim pemasaran Nagari Harau yang tergabung dalam kelompok sadar wisata. Agar tampilan serta kualitas informasi lebih mendalam maka tim pemasaran harus selalu update dengan keadaan Nagari Harau terutama kegiatan yang akan diselenggarakan. Keberadaan website yang sudah ada dapat dijadikan media promosi bagi produk atau hasil usaha masyarakat setempat agar lebih dikenal oleh orang banyak.

\section{DaftarPustaka}

Adhanisa, C., \& Fatchiya, A. (2017). Efektivitas Website Dan Instagram Sebagai Sarana Promosi Kawasan Wisata Berbasis Masyarakat. Jurnal Sains Komunikasi Dan Pengembangan Masyarakat, 1(4), 451-466.

Menteri Pendayagunaan Aparatur Negara dan Reformasi Birokrasi, Peraturan Menteri Pendayagunaan Aparatur Negara dan Reformasi Birokrasi Republik Indonesia Nomor 83 Tahun 2012 Tentang Pedoman Pemanfaatan Media Sosial Instansi Pemerintah 1 (2013). https://doi.org/10.1177/1076029609348647

Brown, M. (2015). Visa Global Travel Intentions Study 2015. https://doi.org/10.1007/978-3-31910241-2_2

Citra, P., Rustanto, R., Rinanto, Y., Keguruan, F., Sebelas, U., Jl, M., Sutami, I., \& Surakarta, K. (2018). Peningkatan Aktivitas Dan Hasil Belajar Kognitif melalui Model STAD disertai Mind Mapping Improving Students 'Activeness and Cognitive Learning Outcomes by using STAD and Mind Mapping. 7, 32-38.

Gifford, J., \& Building, M. (2005). Action Learning: Principles and Issues in Practice Institute For Employment Studies. http://www.employment-studies.co.uk

Hamzah, A. (2015). Pola Penggunaan Situs Jejaring Sosial Sebagai Media Pembelajaran Untuk Mahasiswa. Teknoin, 21(4), 167-177. https://doi.org/10.20885/teknoin.vol21.iss4.art3

Leavitt, M. O. (2006). Research-based web design \& usability guidelines. http://www.usability.gov/ pdfs/guidelines.html

Milano, R. (2011). The Effects Of Online Social Media on Tourism Websites.

Nursastri, S. A. (2013). Kini, Traveling Jadi Prioritas Kedua Orang Indonesia. https://travel.detik.com/travel-news/d-2353478/kini-traveling-jadi-prioritas-kedua-orangindonesia

Prasetya, D. D. (2011). Aplikasi Virtual Tour Berbasis Web sebagai Media Promosi Pariwisata. In Seminar on Electrical, Informatics, And Education 2011 (pp. 58-63). 
http://elektro.um.ac.id/ceie/2011/assets/paper/National/Informatics/A2-10-Didik_Dwi_P-Virtu al Tour Berbasis Web.pdf

Putra, T. (2017). Ekonomi Kreatif Dan Daya Tarik Objek Wisata Studi Kasus Objek Wisata Sikayan Balumuik Kecamatan Pauh Kota Padang. Jurnal Pendidikan Dan Keluarga, 2(4), 36-44. https://doi.org/https://doi.org/10.24036/jpk/vol9-iss1/43

Putra, T. (2019). A Review on Penta Helix Actors in Village Tourism Development and Management. Journal of Business on Hospitality and Tourism, 5(1), 63. https://doi.org/10.22334/jbhost.v5i1.150

Suharto, T. (2005). Konsep Dasar Pendidikan Berbasis Masyarakat. Cakrawala Pendidikan, 3, 323346. https://doi.org/10.21831/cp.v0i3.376

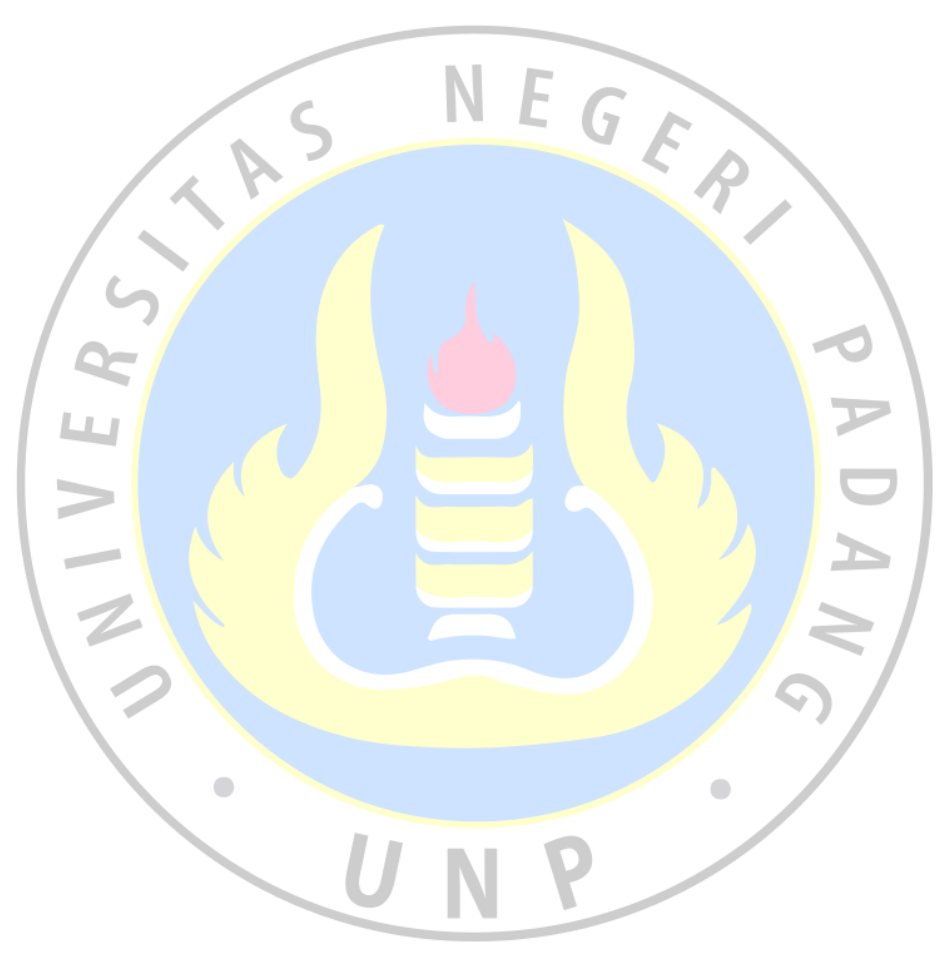

